\title{
Using a Comprehensive Leadership Framework as a Scholarship and Teaching Tool
}

\author{
Kim Boyce \\ Regional Extension Educator, Leadership and Civic Engagement \\ University of Minnesota Extension Service \\ St. Paul, MN \\ boyce003@umn.edu
}

\begin{abstract}
Educators who work in community settings often encounter participants with a wide array of individual leadership beliefs, attitudes, and experiences. Given this situation, one of the challenges we face is to identify effective methods and tools to teach leadership in community and organizational settings. As an educator, it is important to understand and use quality scholarship and theory in leadership education. At the same time, it is important to use educational methods that respect the life experiences of the participants and that are easy to understand and communicate. At the University of Minnesota Extension Service U-Lead program, we seek to balance the academic and scholarship portion of our work with the application of practical tools and methods that connect with the real-life leadership experiences of our participants. The purpose of this paper is to review the comprehensive leadership education framework we currently use and outline how it addresses this balance.
\end{abstract}

\section{Introduction}

I stand near the front of a room filled with over 40 people from a Midwestern community. As I scan the group, I note an equal number of women and men, people between 25 and 70 years old, and a racial and ethic diversity that is representative of the demographic changes occurring in the community. The group members appear eager and excited to talk and learn about leadership. As the conversation begins, it becomes very apparent that members of this group have daily encounters with a variety of leaders' behaviors and leadership styles. Their stories tell how leadership looks and feels very different, depending on the situation. At times leadership is very formal and at other times it is informal. At times leadership is very directive and autocratic and at other times it is very nondirective and open. Sometimes leadership appears to be very public, bold and obvious. Other times leadership appears to be very calm, quiet and filled with humility. Given these widely varied life encounters with leadership behaviors, these participants bring great diversity of opinions and beliefs regarding leadership to this educational setting. As the group members learn about leadership concepts and theories, they look for the links to their life experiences 
and beliefs, and assess the degree to which the "theories" of leadership match the realities of the "practices" of leadership. Often the degree of match between theory and practice is high; however, that is not always the case.

The tension that exists between leadership "practice” and leadership "theory" creates an interesting challenge. From the "practice" point of view, as a professional leadership educator it is important that I honor and acknowledge the wide array leadership beliefs, attitudes, and life experience found in this and other community groups. It is important to demonstrate a level of effective application of leadership skills and practices in the real world and community - leadership that is efficient, useful, and just in solving public problems and enhancing community life. From the "theory" point of view, it is important to pay careful attention to the study and development of quality scholarship and theory - one of the primary functions of the leadership education profession and the academy. As I teach, it is important that I honor my commitment to use a broad base of quality leadership theory and scholarship. The challenge is to determine the best way to balance practical and conceptual tools that will assist community members in both practicing and understanding effective leadership.

Noting this "practical - theoretical” tension is not new to our discipline. Over a decade ago, as he wrestled with this challenge, Dr. Robert W. Terry, then Director of the Center for Reflective Leadership at the Hubert H. Humphrey Institute of Public Affairs, University of Minnesota, proposed that three polarities are the context for examining leadership - "These polarities are the theoretical and the practical, the true and real, and unity and diversity (or the one and the many)" (Terry, 1993, p. 7). These polarities are at the heart of the tension mentioned above. Johnson (1996) describes polarities as interdependent pairs. They exist in relationship with each other, requiring the management of a dynamic balance rather than movement towards a single, static solution. Through his leadership scholarship and practice, Terry (1993) used this principle to develop a comprehensive leadership framework that encompassed the three leadership polarities he identified, and included the six major leadership orientations he observed in scholarship and practice.

My colleagues and I are university employees working in community leadership contexts. We frequently encounter the polarities of "theory - practice," "true real” and "one-many." We have adopted a comprehensive leadership framework in order to find a consistent balance that respectfully engages community members in leadership discussions, while maintaining quality standards for scholarship. The framework enables us to review and integrate scholarship and to guide the development and delivery of leadership education programs and materials that have practical application in community settings.

In this paper I will introduce the framework and the major concepts contained in the framework, and then review the application of the framework to scholarship and teaching. 


\section{Theoretical Base}

The quest to classify, catalog, sort and understand the breadth of leadership scholarship and practice is not new. The works of Stogdill (1981), Kellerman (1984), Bass (1990), and Northouse (2001) represent well-known writings that provide a broad perspective on the theory and practice of leadership, and are frequently cited in leadership literature reviews. New conceptual models and ideas for core leadership curriculums such as those discussed by Watt (2003) and Bridgeforth (2005) are just two examples of the continued attention given to this topic. Recently I reviewed the Encyclopedia of Leadership, a comprehensive fourvolume collection of leadership related information edited by Goethals, Sorenson, and Burns (2004) that details multiple perspectives on leadership theories and practices. When it comes to leadership models and frameworks it is obvious that there are many possible options from which to choose.

Recognizing there will always be many credible leadership frameworks to choose from, the faculty and staff of the University of Minnesota Extension Service began to adopt the use of a comprehensive leadership framework to assist in the development and delivery of leadership education programs and materials. This effort began informally about a decade ago and the framework was formally adopted in 2003. We worked closely with University of Minnesota faculty and staff at the Hubert H. Humphrey Institute of Public Affairs, including Dr. Robert Terry. In 1993 Terry authored, Authentic Leadership: Courage in Action. His book provides a broad review of existing leadership theory and scholarship, and groups the variety of different perspectives into a framework consisting of six major views of leadership. That same year, the North Central Regional Center for Rural Development published, Leadership: Sustaining Action on Community and Organizational Issues, a leadership education resource book based on the same Terry framework. A decade later Crosby, Bryson and Anderson (2003) used a similar framework in the development of materials related to leadership and community decision-making. Terry (2001) continued the use of the framework as he further summarized and explored concepts of leadership and the relationship with the concepts of authentic behavior, as well as leadership behavior in situations that are stable or chaotic.

\section{The Framework and How it Works}

Using the Terry $(1993,2001)$ framework, members of the University of Minnesota Extension Service - Leadership and Civic Engagement area of expertise have developed specific educational materials and activities that build upon the theory and scholarship connected with each of his six leadership views. They have proven to be of practical use for community leaders. Here is an overview of the six leadership views followed by a brief review how we apply the framework to scholarship and teaching. 
Figure 1. Graphic representation of the six leadership views in the framework (Boyce, 1999)

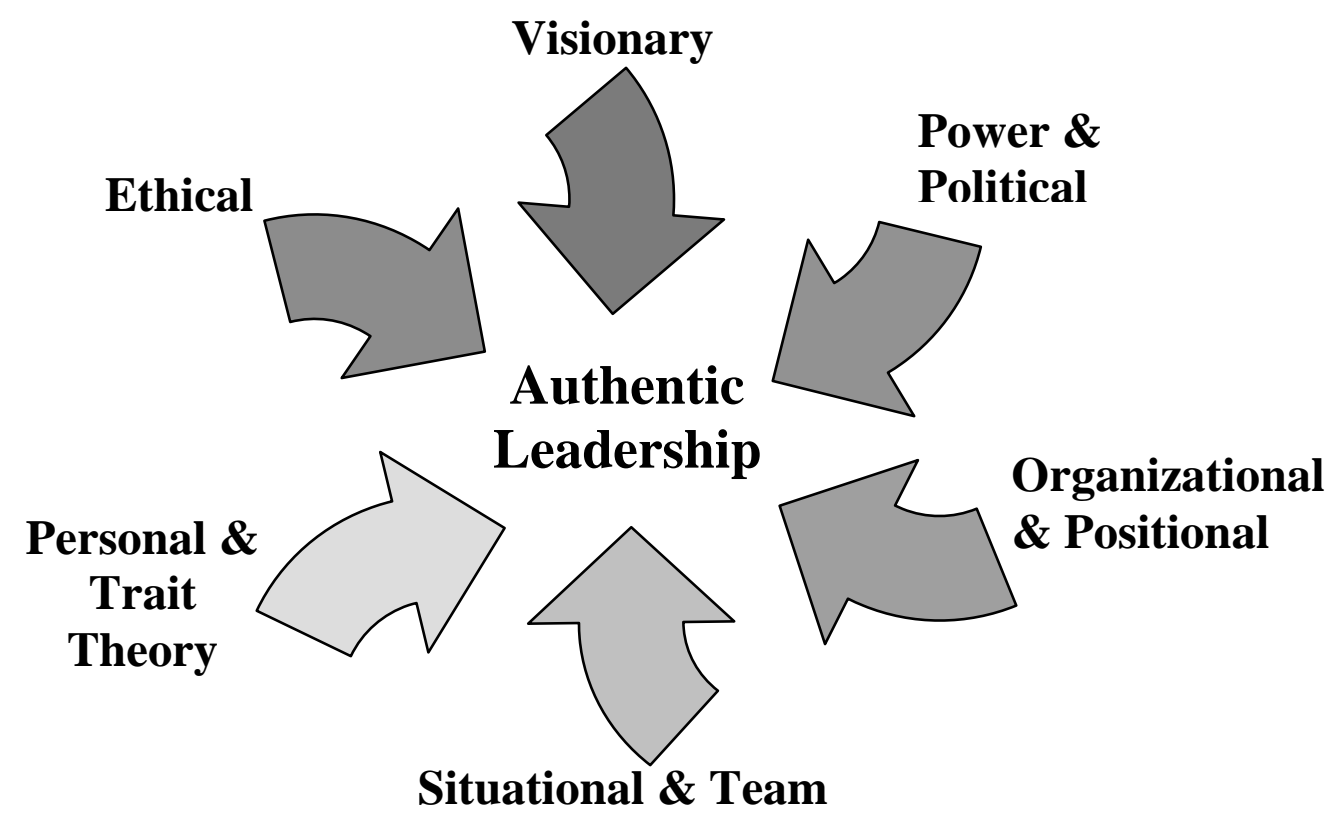

\section{Personal/Trait Theory Leadership}

Key concepts: Leadership is linked to biological and inborn traits - some people are born to be leaders, others are not, and/or everyone can lead, but their leadership behavior will vary depending on their personal style. Assessing personal skills, preferences, strengths and weaknesses, and understanding personal styles of leadership are part of the personal/trait theory view. The personal/trait theory view is also the portion of the leadership framework that connects to the concept of existence - addressing the question, "What is the history of the person, group, or community?” Examples of scholarship in the personal/trait theory leadership view include: Myers and Briggs-Myers (1995), Pearman (1998), and Barrick and Mount (1991).

\section{Situational/Team Leadership}

Key concepts: Leadership is fluid, dynamic and changing - dependent on the needs of the group. Everyone has the potential to lead and to be a group member. The role of the leader is to help the group move to the desired goal by using different leadership skills/techniques at appropriate times. The situational/team leadership view is also the portion of the leadership framework that connects to the concept of resources - addressing the question, "What are the types of resources needed for success?” Examples of scholarship in the situational/team leadership view include: Hersey (1984), Hersey and Blanchard (1993), Murphy (1996), Parker (1990), and Katzenbach and Smith (1993). 


\section{Organizational/Positional Leadership}

Key concepts: Leadership is connected to organizational position and role. Leadership responsibilities differ among levels of the organization, and a role of leadership is to create and adapt the organizational structures and processes to work as effectively as possible. Leadership can be defined by the behaviors, skills and activities exhibited by those in positions of organizational influence. The organizational/positional leadership view is also the portion of the leadership framework that connects to the concept of structure - addressing the question, "What are the plans, processes and systems used to organize the work?"

Examples of scholarship in the organizational/positional leadership view include: Bennis and Nanus (1985), Kouzes and Posner (1995), and Belasco and Stayer (1993).

\section{Power/Political Leadership}

Key concepts: Leadership is connected to getting something done - initiating change. Leadership is viewed as (a) moving forward a personal agenda, and/or (b) the empowerment and engagement of others. Leaders must have the skills to work successfully in formal and informal systems, deal with power and conflict, build coalitions, and address issues of participation and involvement. The power/political leadership view is also the portion of the leadership framework that connects to the concept of power - answering the questions, "What is the level of commitment with those who are stakeholders?" and "What are the dynamics between those involved in this issue?” Examples of scholarship in the power/political leadership view include: Boyte (1989), Block (1987), Bryson and Crosby (1992), and Tichy (1997).

\section{Visionary Leadership}

Key concepts: Leaders help others to critically examine "the present" - and leaders provide a sense of direction for "the future." Thinking "outside" the existing system is encouraged. Developing scenarios, possibilities for the future, and doing that which has not been done before is expected. The visionary leadership view is also the portion of the leadership framework that connects to the concept of mission - addressing the question, "What is the purpose, direction or mission of what we are trying to accomplish?” Examples of scholarship in the visionary leadership view include: Wheatley (1993), Kotter (1996), Adams (1986), Renesch (1994), and Senge (1990).

\section{Ethical Leadership}

Key concepts: Leadership is concerned about "doing the right thing" - moving toward a beneficial end or common good. Leadership assesses why something should be done, what is to be done, and the values that underlie the situation. Leadership engages followers in a respectful, voluntary and community- 
enhancing relationship. The ethical leadership view is also the portion of the leadership framework connected to the concept of meaning - addressing questions of "What is at stake here?" and "What are the right things to do?" Examples of scholarship in the ethical leadership view include: Burns (1987), Covey (1991), Kidder (1995), Greenleaf (1997), Ciulla (1998), and Kouzes and Posner (1993).

The six views of leadership function as an integrated system. Effective leadership requires knowledge and attention to all six areas simultaneously. Terry (1993) referred to this integration of all the leadership views as "authentic leadership."

\section{Authentic Leadership}

Engaging in all of the above - being true to self and true to the world; leading to fulfillment - understanding the honoring the promises made to all stakeholders.

\section{Application to Scholarship and Teaching}

The Terry $(1993,2001)$ framework serves as an "organizing template” for current leadership programs that are designed and/or developed by the University of Minnesota Extension Service. Materials and activities have been designed to teach the overall framework, as well as each of the six leadership views. Educational workshops ranging from four to twelve hours in length have been developed to discuss each leadership view in community contexts. The University of Minnesota Extension Service is currently reviewing and revising the core curriculum for $U$-Lead programs. We continue to use the Terry framework as a conceptual tool to organize and update our leadership education materials. The revisions are anticipated to be completed within a year.

The framework is based on broad leadership concepts and is dynamic, easily allowing for the integration and inclusion of new scholarship and research. It maintains a base that builds upon previous scholarship, research and experience. For example, as new research and scholarship in the areas of ethical leadership or organizational leadership become available, that information can easily be introduced and included in those sections of the framework.

We are intentionally transparent with the use of the framework. Frequently, during the first session of a multi-session leadership program, an overview of the entire framework is shared with participants. Then specific modules are used at subsequent sessions to more deeply explore each of the six leadership views. The theoretical model of the framework includes the assumption that understanding and integrating all of the leadership views is required for effective leadership.

The framework is used as we design and develop the content for new Extension leadership programs, and also in consultations with other groups as they design leadership programs. The six core areas are used as a systematic method to review the proposed leadership concepts and tools for a particular program and to 
determine if there are leadership perspectives that have been overlooked, overemphasized or that should be added and modified.

On some occasions educational materials and activities related to a particular leadership view are used independently if those materials and activities match the educational interests and needs of a particular group or organization. For example, an existing organizational or community-based leadership program might request that Extension conduct a half-day or full-day workshop on the topic of "ethical leadership" to expand upon or enhance an existing leadership education curriculum they currently use in that organization or community.

With six primary conceptual points, the framework is simple enough that participants find it easy to understand and to remember the leadership concepts. The framework draws upon scholarship and theory, yet does not overwhelm participants with great complexity. However, if participants want to learn more about one or more of the particular views of leadership they can easily access the scholarly writing and theory and explore a particular leadership view.

By systematically reviewing leadership concepts using the framework, participants are able to identify where their particular life experiences, opinions and beliefs related to leadership reside. The framework easily links life experience to theoretical concepts. Participants are able to notice if a majority of their experiences and opinions connect with only a few particular areas of the framework. For example, participants might recognize that they tend to spend most of their energy and focus on issues of ethics and vision, paying little attention to the organizational or team perspectives of leadership. This recognition may help the participants understand how they can best use their strength and experience in ethics and visioning, and when they need to draw upon the strengths and experience of others in areas of organization and team leadership.

As leadership concepts and perspectives are introduced and reviewed with participants, the framework challenges participants to thoughtfully wrestle with their existing attitudes, perspectives and views of leadership. The framework serves as a tool to help participants sort and examine the multiple leadership experiences they have and will encounter.

During the past year, over 85 people have participated in half-day leadership education workshops that use the Terry $(1993,2001)$ framework. Workshop evaluations, using a retrospective survey technique, find participants reporting increases ranging from $27.7 \%$ to $50 \%$ in "their understanding of views and theories of leadership."

\section{Conclusion}

Using a comprehensive leadership framework that is scholarly-based has proven to be a valuable tool in leadership education program design and delivery for the 
University of Minnesota Extension Service. The framework is broad and dynamic allowing for the inclusion of new and emerging scholarship while building upon existing scholarship and not requiring a restructuring of the framework. The framework is useful as a design tool to examine and build leadership education programs, materials and activities. The six major components of the framework are easy to understand and remember. The breadth of the framework allows for a systematic examination of leadership perspectives, the respectful integration of participant life experience, opinions and beliefs regarding leadership, and a useful tool to clearly communicate leadership concepts. The framework serves as an effective tool to balance the demands of scholarship and teaching. 


\section{References}

Adams, J. D. (1986). Transforming leadership: From vision to results. Alexandria VA: Miles River Press.

Barrick, M. R., \& Mount, M. K. (1991). The big five personality dimension and performance: A meta-analysis. Personnel Psychology, 44(1), 1-26.

Bass, B. M. (1990). Bass \& Stogdill's handbook of leadership: Theory, research and managerial applications ( $3^{\text {rd }}$ ed.). NewYork: Free Press; London: Collier Macmillan.

Belasco, J. M., \& Stayer, R. C. (1993). The flight of the buffalo: Soaring to excellence, learning to let employees lead. New York: Warner Books.

Bennis, W., \& Nanus, B. (1985). Leaders: Strategies for taking charge. New York: Harper \& Row.

Block, P. (1987). The empowered manger: Positive political skills at work. San Francisco: Jossey-Bass.

Boyce, K. N. (1999). Views of leadership. Unpublished leadership education materials, University of Minnesota Extension Service, St. Paul, MN.

Boyte, H. C. (1989). Commonwealth: A return to citizen politics. New York: Free Press.

Bridgeforth, B. W. (2005, Summer). Advancing the practice of leadership: A curriculum. The Journal of Leadership Education, 4(1), pp.4-30.

Bryson, J. M., \& Crosby, B. C. (1992). Leadership for the common good:

Tackling public problems in a shared-power world. San Francisco: Jossey-Bass.

Burns, J. M. (1978). Leadership. New York: Harper \& Row.

Covey, S. (1991). Principle-centered leadership. New York: Summit Books.

Crosby, B. C., Bryson, J.M., \& Anderson, S. (2003). Leadership for the common good fieldbook: Tools for working in a shared-power world. Minneapolis, MN: University of Minnesota.

Ciulla, J. B. (1998). Ethics, the heart of leadership. Westport, CT: Greenwood.

Greenleaf, R. (1977). Servant-leadership: A journey into the nature of legitimate power and greatness. New York: Paulist Press. 
Goethals, G. R., Sorenson, J. G., \& Burns, J. M. (Eds.) (2004). Encyclopedia of Leadership. Thousand Oaks, CA: Sage Publications Inc.

Hersey, P. (1984). The situational leader. Escondido, CA: Center for Leadership Studies.

Hersey, P., \& Blanchard, K. H. (1993). Management and organizational behavior: Utilizing human resources ( $6^{\text {th }}$ ed.). Englewood Cliffs, NJ: Prentice Hall.

Johnson, B. (1996). Polarity management: Identifying and managing unsolvable problems. Amherst, MA: HRD Press.

Katzenbach, J. R., \& Smith, D. K. (1993). The wisdom of teams: Creating the high-performance organization. New York: McKinsey \& Company;

HarperCollins Publishers.

Kellerman, B. (Ed.) (1984). Leadership: Multidisciplinary approaches. Englewood Cliffs, NJ: Prentice Hall.

Kidder, R. M. (1995). How good people make tough choices: Resolving the dilemmas of ethical living. New York: Fireside Books; Simon \& Schuster.

Renesch, J. (Ed.) (1994). Leadership in a new era: Visionary approaches to the biggest crisis of our time. San Francisco: New Leaders Press; Sterling\& Stone.

Kotter, J. P. (1996). Leading change. Boston, MA: Harvard Business School Press.

Kouzes, J., \& Posner, B. (1995). The leadership challenge: How to get extraordinary things done in organizations ( $2^{\text {nd }}$ ed.). San Francisco: Jossey-Bass.

Kouzes, J., \& Posner, B. (1995). Credibility: How leaders gain and lose it. Why people demand it. San Francisco: Jossey-Bass.

Murphy, E. C. (1996). Leadership IQ, New York: John Wiley and Sons.

Myers, I., \& Briggs-Myers, P. (1995). Gifts differing: Understanding personality type. Palo Alto, CA: Davies-Black Publishing.

Northouse, P. G. (2001). Leadership: Theory and practice ( $2^{\text {nd }}$ ed.). Thousand Oaks, CA: Sage Publications.

Parker, G. M. (1990). Team players and teamwork. San Francisco: Jossey-Bass. 
Pearman, R. R. (1998). Hardwired leadership: Unleashing the power of personality to become a new millennium leader. Palo Alto, CA: Davies-Black Publishing.

Senge, P. M. (1990). The fifth discipline: Mastering the five practices of the learning organization. New York: Doubleday Currency.

Terry, R. W., \& NCRCRD (1993). Leadership: Sustaining action on community and organizational issues. Ames, IA: North Central Regional Center for Rural Development and Iowa State University Printing Services.

Terry, R. W. (1993). Authentic leadership: Courage in action. San Francisco: Jossey-Bass.

Terry, R. W. (2001). Seven zones for leadership: Acting authentically in stability and chaos. Palo Alto, CA: Davies-Black Publishing.

Tichy, N. M. (1997). The leadership engine: How winning companies build leaders at every level. New York: HarperCollins Publishers.

Stogdill. R. M. (1981). Stogdill's handbook of leadership: A survey of theory and research. New York: Free Press.

Watt, W. M. (2003, Summer). Effective leadership education: Developing a core curriculum for leadership studies. The Journal of Leadership Education, 2(1), pp. 13-26.

Wheatley, M. (1993). Leadership and the new science. San Francisco: BerrettKoehler.

\section{Biography}

Kim Boyce is a Regional Extension Educator and Professor with the University of Minnesota Extension Service. He specializes in leadership and civic engagement, with particular emphasis on public and natural resources sectors, including elected officials. His career includes 17 years of Extension experience and 12 years in the non-profit sector. 